\title{
Ugolino's Supposed Cannibalism: A Bibliographical Note
}

Robert Hollander

Ugolino's narration of the horrifying week during which he and his children were starved to death by the agents of Archbishop Ruggieri ends with a verse that causes greater difficulty than is perhaps warranted:

"Poscia, piú che 'l dolor, poté 'l digiuno."1

("Then fasting had greater effect than grief.")

While, with only few exceptions, the first five centuries of the commentary tradition took the line to mean only that Ugolino died of starvation, the last one hundred and sixty years have witnessed the emergence of one of the most vexing controversies that currently exists among exegetes of the Commedia. This fairly recent crux interpretum receives various resolutions. The majority of modern commentators would agree with the general sense offered in my own translation (above), and either assumes or reasons that the verse signifies exactly what it seems to assert, namely that Ugolino's week-long deprivation of any nourishment finally overcame the last energy of which he was aware as promoting his will to live, that of grief. Others, as is well known, assert that Dante is here intentionally ambiguous, having left the possibility of a cannibalistic atrocity balanced in our minds. Still others - a small but growing minority - hold that we should understand no less than that the verse requires us to understand that he bit into the flesh of the dead children in a last despairing attempt to nourish himself.

In a recent article I have argued that the central drama of the concluding portion of Ugolino's narrative (XXXIII. 37-74) lies elsewhere than is usually perceived. In my view the suppressed revelation - one that Dante hoped we would read between Ugolino's 
lines - concerning this horrified and horrifying sinner is nothing other than his own failed paternity. In this reading Luke's gospel, and in particular the parable of the importunate friend (Luke 11: 5-13), becomes the most pertinent antecedent text that conduces to a clearer understanding of the desperate drama of this problematic canto. ${ }^{2}$ If this perception of a palimpsestic presence of Luke's parable is convincing, if a reader believes that Ugolino's spiritual failure is the most important fact which we discover about him when we consider his words with circumspection, then we may find ourselves less ready to consider him a sympathetic or a noble victim of Ruggieri's cruelty than has been many a previous reader. It might then also seem reasonable to expect that such an understanding of Ugolino's wider culpability would lend support to those who claim that he ingested the flesh of the children. It is, however, my opinion that acceptance of such a reading, which has a sole early champion in Jacopo della Lana, ${ }^{3}$ adds a dimension to the scene which is probably gratuitous, given the importance of Ugolino's spiritual failure. It would have been strange, I think, for Dante to have wished to conclude an episode which is concerned with carnal misinterpretation of spiritual truth by inviting us - with whatever degree of ambiguity - to make a carnal interpretation of Ugolino's last utterance. The four recent American proponents of a cannibalistic reading, Shapiro (1974), Freccero (1977), Cook/Herzman (1979), and Herzman (1980), are among the few discussants since Pietrobono (1946) and Raya (1955) to insist upon this spectacular but unlikely interpretation. ${ }^{4}$

Earlier reviews of the crux interpretum that should be consulted include Blanc (1861), pp. 316-21; Scartazzini (1874 - but see his fuller bibliography in 1900); Poletto (1894) - the first modern commentator to suggest that, if Ugolino did not ingest the flesh of the dead children, he at least momentarily attempted to do so; Murari (1898); D'Ovidio (1907); Ricci $\left(1921^{2}\right)$. D'Ovidio offers the single most exhaustive review of the problem which we possess (pp. 63-116 are devoted to "Le ultime parole di Ugolino"; but see also pp. 3-60, which discuss "L'episodio di Ugolino" and pp. 119-40, which confront "L'Ugolino del De Sanctis"). It is surprising that so few contemporary discussants make use of this essential and sensible work. ${ }^{5}$ It is probably significant that nearly all who have devoted a major effort to the history of the interpretation of the verse reject the cannibalistic reading. ${ }^{6}$

What follows is a tabular review of the history of the debate put forward in the hope that future students of the problem will find 
some of their task accomplished. This form of representation does not allow for the shadings which one finds in at least some of the arguments as they are advanced. It does reveal the fluctuating nature of critical debate, as well as the tendency of any given critical position to replicate itself. ${ }^{7}$

Ugolino died of hunger

Ugolino died of hunger; he did not eat (or try to eat) children

Verse ambiguous, Ugolino ate (or but lends credence tried to eat) the to notion of canni- children balism

Guido da Pisa

(1327)

Ottimo (1333)

Pietro di Dante

(1358?)

Benvenuto (1373)

Buti (1385)

Anon. Fiorentino

(1400?)

Serravalle (1416)

Guiniforto (1440

ca.)

Vellutello (1544)

Nidobeato (1477)

Daniello (1568)

Venturi (1732)

Lombardi (1791)

Biagioli (1818)

Costa (1819)

Cesari (1824)

Rossetti (1826)

Arrivabene (1827)

Borghi (1827)

Tommaseo (1837)

"Philalethes"

(1839)

Zani de' Ferranti

Viviani (1823)

(1855)

Gregoretti (1856)

L. Martini (1840)

B. Bianchi (1844)

Fraticelli (1852)

Lambri di

Longiano (1854)

Andreoli (1856)

M. Romani

(1858) 


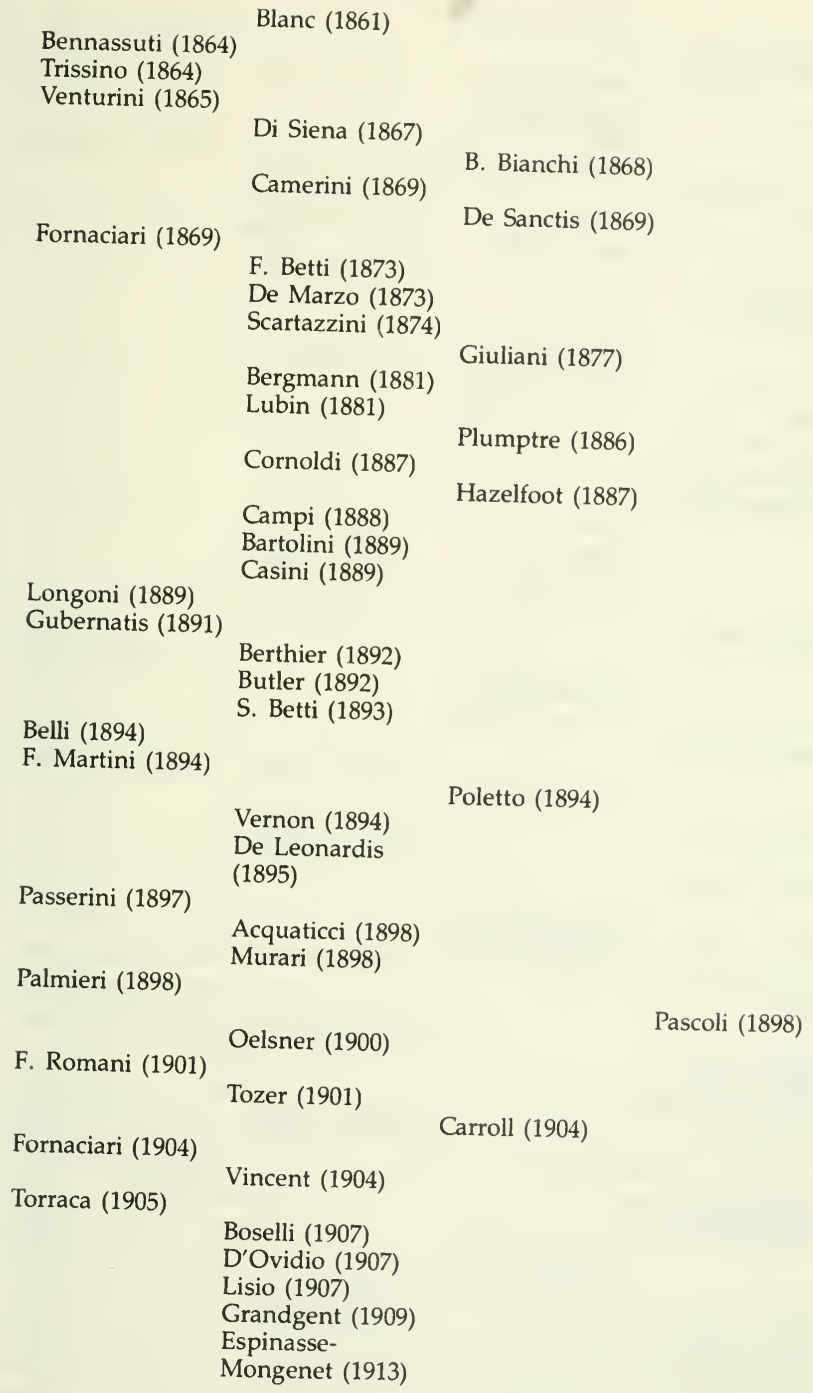


Langdon (1918)

Mestica (1921)

Rossi (1923)

G. Mazzoni

(1924)

G. A. Venturi

(1924)

Pompeati (1925)

Del Lungo (1926)

Tamburini (1926)

Howell (1931)

Vitali (1943)

Rivalta (1946)

Villaroel (1947)

Malagoli (1955)

Soprano (1955)

Montanari (1956)

Bianchi/Manetti (1962)

Johnston (1928)

Folingo (1929)

Scartazzini/

Vandelli (1929)

Grabher (1934)

Trucchi (1936)

Provenzal (1938)

Porena (1946)

Spoerri (1946)

Lepore (1950)

Falchitto (1952)

Gmelin (1954)

Sapegno (1955)

Raya (1955)

Mattalia (1960)

Ammendola

(1962)

Chimenz (1962)

Sbriccoli (1963)

Marcazzan (1962)

Morvidi (1962)

Fallani (1965)

Contini (1965) 
Pézard (1965)

Ramat (1965)

Russo (1966)

Bargellini (1968)

Sortino (1967)

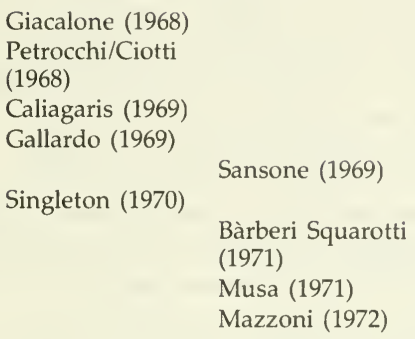

Bosco (1976)

Shapiro (1974)

Cioffari (1977)

Lonergan (1977)

Freccero (1977)

Bosco/Reggio

(1979)

Pasquini (1980)

Cook/Herzman

(1979)

Boitani (1981)

Pasquini/Quaglio

(1982)

While I would be the last to suggest that a "majority vote" among the commentators is in itself convincing evidence for a given interpretive position, I do think that the history of the debate is instructive on several grounds.

1) Lana's (1324) position, whether it was his or an anonymous copyist's, was available from the earliest days of the exegetical tradition. That it received no support from other early commentators (and was strongly opposed by Buti [1385], who is generally conceded to have been the most knowledgeable local historian of things Pisan) is probably to be considered a serious objection to the validity of the more melodramatic reading.

2) Niccolini's resuscitation of Lana's reading (see note 6), while it did occasion a nineteenth-century debate of some acerbity, did not eventuate in extensive scholarly attention to that debate, which remains an interesting curiosity, but not an important contribution toward resolving the difficulty. 
3) De Sanctis (1869), on the other hand, is the true father of the modern cannibalistic interpretation. Yet even such as Raya (1955) have complained that his reading is far too cautious. De Sanctis actually argued for the probable correctness of the traditional interpretation, going on to suggest that the line was - whatever Dante's intention - ambiguous, that it allowed for, if it did not finally sanction, such a reading. It is surprising that so many who align themselves with De Sanctis's interpretation use it to support a far less delicate critical response to the verse.

If a given reader of a text perceives something in it, one who does not see that something runs the risk of playing Polonius to that observer's Hamlet. The shape of poetic utterance, like that of a cloud, tends to call up subjective responses. To those who find the cannibalistic interpretation attractive, one who does not do so can only offer his scepticism. There are no proofs in such matters. On the other hand, those who seek to prove the cannibal's case by drawing our attention to the many images of eating in cantos XXXII and XXXIII — as has several times been done - may be reproved. Are we to understand that Tydeus, because he gnawed on the freshly severed head of Malanippus (Thebaid VIII. 751-66 the source of Dante's horrific description of Ugolino and Ruggieri), will also be found punished in hell as a "cannibal"? Or that Lucifer, chewing on three sinners (and indeed on the head of Judas) should be similarly regarded? It is probably more sensible to believe that the cannibalism which we find enacted here in Dante's pages points beyond itself to a spiritual condition, that it is not so much reflective of the literalist's desire to find a carnal cause as it is of a deliberately wrought poetic effect.

\section{Princeton University}

\section{NOTES}

1 The text is drawn from Petrocchi (1966). For this and all following references to Dante's commentators, see the chronologically ordered Bibliographical Note which follows these remarks. I would like to acknowledge the contributions to this investigation of my research assistant at Princeton University, Timothy Hampton, and of the staff of Special Collections at the John M. Olin Library at Cornell University, as well as that of Interlibrary Services at Princeton's Firestone Library.

2 See Robert Hollander, "Inferno XXXIII, 37-74: Ugolino's Importunity," forthcoming in Speculum (1984?). Perhaps the focal verse in Luke is "If a son shall ask bread of any of you that is a father, will he give him a stone?" (11:11). In my interpretation, Ugolino's stony silence (see Inf. XXXIII. 49: ". . sí dentro 
impetrai") reveals his failure to assume even the minimally responsive role attributed to the father in the parable.

3 Two pieces of information may undermine the importance of this singular early reading. First, Scarabelli, the editor of Lana (1324), points out (pp. 501-02) that one MS (the Magliabecchiano) simply reads "qui mostra che furono morti, il digiuno vinse il dolore." Scarabelli speculates that the [rather jumbled] continuation found in other MSS may result from a later anonymous interpolation: ". . . dolore, ch'elli mangiò d'alcuni di quelli. Infine morí pure di fame perché non durò che non putrefacessero le loro carni." Second, it is this reading which later appears verbatim in the compilation of earlier commentators published in 1477 (Venice, Vendelin da Spira - see the Catalogue of the Cornell Dante Collection, pp. 3-4) and in Nidobeato (1477), a similar compendium. Whether or not the notice of the cannibalistic conclusion to the episode is Lana's or another's, we can say that there was only one source of this interpretation which we have to date been able to locate. Both that fact and the formulation of what Ugolino purportedly did (began to ingest the flesh of the children but then disgustedly ceased - a rather colorful inference to make from the bare bones of the verse) tend to reduce the authority of the comment. It is advanced with less dubiety than its nature should summon by some of those who discuss this problem.

4 Mattalia (1960) "officially" opts for an ambiguous meaning, but confesses a personal preference for the more flamboyant reading. Like Poletto (1894), Pietrobono is drawn to the cannibalistic hypothesis, but retreats from fully embracing it: "L'espressione è volutamente misteriosa," he says; he continues by arguing that this possible reading of a possible action may be justified by other references to eating in the surrounding text. Enlarging upon this observation, Raya (1955) was the first to offer an aggressive argument in favor of a cannibalistic interpretation.

5 For more recent responses see Russo (1966) and Bosco (1976), p. 799.

6 But see Raya (1955), who puts forth seven reasons for believing that the verse should be taken as indicating that Ugolino ate the children. His article offers a review of the local and passionate nineteenth-century debate - one that, because of its amateurish bearing and legalistic tone has not often entered into the commentary tradition (and is not reflected in the text of this discussion or in the following table - initiated by G. Niccolini, who in 1825 resuscitated the interpretation attributed to Jacopo della Lana, in which Carmignani and Rosini were the major adversaries (the former in the service of the Lanean thesis). See also Ricci $\left(1921^{2}\right)$, pp. 227-28.

7 For full bibliographical entries for each of the discussants in the following table see the Bibliographical Note. With regard to the table itself it should be explained that some later commentators who interpret the verse to mean only that Ugolino starved to death are in implicit polemic with those who propose that the verse allows us to believe that he ate (or attempted to eat) the children; others seem not to want to enter the controversy or do not care (or perhaps even know) that it exists. Since it is not possible to make such distinctions with certainty, I have merely reported each absolute verdict as accurately as I was able to do.

\section{BIBLIOGRAPHICAL NOTE}

Lana (1324)

Guido da Pisa (1327)
Comedia di Dante degli Allaghieri col Commento di Jacopo della Lana bolognese, a cura di Luciano Scarabelli. Bologna: Tipografia Regia, 1866-67.

Guido da Pisa's Expositiones et Glose super Comediam Dantis, or Commentary on Dante's Inferno, edited with Notes and an Introduction by Vincenzo 
Ottimo (1333)

Benvenuto (1373)

Buti (1385)

Anon. Fiorentino (1400?) Commento alla Divina Commedia d'Anonimo Fiorentino del secolo XIV, ed. Pietro Fanfani. Bologna: G. Romagnoli, 1866-74.

Serravalle (1416)

Guiniforto (1440 ca.) Lo Inferno della Contmedia di Dante Alighieri col comento di Guiniforto delli Bargigi, ed. G. Zac[c]heroni. Marseilles, L. Mossy \& Florence: G. Molini, 1838.

Nidobbato (1477) La Contedia di Dante Aldighieri, excelso poeta fiorentino. Milan: [Ludovicus \& Albertus Pedemontani for Martino Paolo Nidobeato \& Guido Terzago], 1477-78.

Vellutello (1544) La Comedia di Dante Aligieri con la noza espositione di Alessandro Vellutello. Venice: F. Marcolini, 1544.

Daniello (1568)

Dante con l'espositione di M. Bernard[in]o Daniello da Lucca sopra la sua Comedia dell' Inferno, del Purgatorio, $\mathcal{E}$ del Paradiso. . . . Venice: Pietro da Fino, 1568 .

Venturi (1732)

Lombardi (1791)
La Divina Commedia di Dante Alighieri. . . col comento del P. Pompeo Venturi. Florence: L. Ciardetti, 1821.

La Divina Commedia, novamente corretta, spiegata e difesa da F. B. L. M. C. [i.e., Fra Baldassare Lombardi, minore conventuale]. Rome: A. Fulgoni, 1791[-92]. 
Biagioli (1818)

Costa (1819)

Viviani (1823)

Cesari (1824)

Rossetti (1826)

Arrivabene (1827)

Borghi (1827)

Tommaseo (1837)

"Philalethes" (1839)

L. Martini (1840)

B. Bianchi (1844)

Fraticelli (1852)

Lambri di Longiano (1854) La Divina Commedia di Dante Allighieri all'intelligenza di tutti; studio d'un Solitario [i.e., P.I. Lambri di Longiano], 3rd ed. Florence: P. Fioretti, 1864.

Zani de' Ferranti (1855) Di varie lezioni da sostituirsi alle invalse nell' "Inferno" di Dante Alighieri. Bologna: Marsigli e Rocchi, 1855, pp. 145-46.

Andreoli (1856)

Gregoretti (1856)

La Divina Commedia di Dante Alighieri col comento di G[iosafatte] Biagioli. Paris: Dondey-Dupré, 1818-19. La Divina Commedia con brevi note di Paolo Costa. Bologna: Cardinali e Frulli, 1826-27.

La Divina Commedia di Dante Alighieri giusta la lezione del codice bartoliniano [ed. Q. Viviani]. Udine: Fratelli Mattiuzzi, 1823.

Bellezze della Divina Commedia di Dante Alighieri: Dialoghi d'Antonio Cesari. Verona: P. Libanti, 1824-26.

La Divina Commedia di Dante Alighieri con comento analitico di Gabriele Rossetti. London: John Murray, 1826-27. telli Mattiuzzi, 1827.

La Divina Commedia con nuovi argomenti e note [di G. B(orghi)]. Florence: P. Borghi, 1827.

La Divina Commedia con le note di Niccolò Tommaseo $e$ introduzione di Umberto Cosmo. Turin: UTET, 1927-34 [repr. of 2nd ed., 1865].

Commento del re Giovanni di Sassonia (Filalete) alla "Divina Commedia." Italian translation of notes to Inferno in Propugnatore, XX, 1 (1887), 334-70; XX, 2 (1887), 64-108; 352-83; L'Alighieri, I (1889)-IV (1893), passim.

La Divina Commedia di Dante Alighieri dichiarata secondo i principii della filosofia per Lorenzo Martini. Turin: G. Marietti, 1840.

see B. Bianchi (1868)

La Divina Commedia di Dante Alighieri col comento di P[ietro] Fraticelli. Nuova ediz. con giunte e correzioni. . . . Florence: G. Barbèra, 1886 [1887?].

La Divina Commedia di Dante Alighieri col Commento di Raffaello Andreoli. Florence: G. Barbèra, 1887. La Commedia di Dante Allighieri interpretata da Francesco Gregoretti, $2^{a}$ ediz., corretta e ampliata. Venice: M. Visentini, 1869. 
M. Romani (1858)

Blanc (1861)

Bennassuti (1864)

Trissino (1864)

Venturini (1865)

Di Siena (1867)

B. Bianchi (1868)

Camerini (1869)

De Sanctis (1869)

Fornaciari (1869)

F. Betti (1873)

De Marzo (1873)

Scartazzini (1874)
La Divina Commedia di Dante Allighieri spiegata al popolo di Matteo Romani arciprete di Campegine. Reggio: G. Davolio, 1858-61.

Saggio di una interpretazione filologica di parecchi passi oscuri e controversi della "Divina Commedia" per L. G. Dr. Blanc, con proemio, osservazioni ed aggiunte di O. Occioni: "l'Inferno." Trieste: C. Coen, 1865.

La Divina Commedia di Dante Alighieri col commento cattolico di Luigi Bennassuti, arciprete di Cerea. Verona: G. Civelli, 1864-68.

La Divina Commedia di Dante Allighieri esposta in prosa a comune intelligenza dal conte Francesco Trissino, 2nd ed. Milan: G. Schiepatti, 1864 (1st ed. 1857-58).

La Divina Commedia di Dante Alighieri recata alla popolare intelligenza da Domenico Venturini. Rome: Tipografia Tiberina, 1865.

Commedia di Dante Alighieri con note di Gregorio di Siena, Inferno. Naples: Perrotti, 1867-70.

La Commedia di Dante Alighieri, novamente riveduta nel testo e dichiarata da Brunone Bianchi. Florence: Successori Le Monnier, $1868[=7$ th ed. of the commentary by Costa (1819); Bianchi first made Costa's commentary substantially his own in the 3rd ed.: La Divina Commedia di Dante Alighieri col comento di P. Costa notabilmente accresciuto dell'abbate Brunone Bianchi. Florence: Le Monier, 1844.] La Divina Commedia di Dante Alighieri con note tratte dai migliori commenti per cura di Eugenio Camerini. Milan: E. Sanzogno, 1869.

Francesco De Sanctis, "L'Ugolino di Dante," in his Opere, vol. V. Turin: Einaudi, 1967, pp. 681-704.

Raffaello Fornaciari, "L'arte di Dante nell' episodio d'Ugolino," Il Propugnatore, II, 2 (1869), 172-80.

Comento della Divina Commedia di Ippioflauto Tediscen [pseudonym of F. Betti], pubblicato per cura dei suoi amici F. Barotta e F.S. Cianci. Vasto \& Lanciano: D. Masciangelo, 1873[-78].

Studi filosofici, morali, estetici, storici, politici, filologici su la Divina Commedia di Dante Alighieri del prof. Antonio Gualberto De Marzo [= Commento su la Divina Commedia]. Florence: Tipografia Dante, 1873 [Inf.; Purg. 1877; Par. 1881].

La Divina Commedia di Dante Alighieri riveduta nel testo e commentata da G.A. Scartazzini. Leipzig, F.A. Brockhaus, $1874-90$. [And see $2^{\mathrm{a}}$ ediz. intie- 
Giuliani (1877)

Bergmann (1881)

Lubin (1881)

Plumptre (1886)

Cornoldi (1887)

Hazelfoot (1887)

Campi (1888)

Bartolini (1889)

Casini (1889)

Longoni (1889)

Gubernatis (1891)

Berthier (1892)

Butler (1892)

S. Betti (1893)

Belli (1894) ramente rifatta: Leipzig: Brockhaus, 1900 (rist. Bologna: Forni, 1965); see also Vandelli (1929).

G.B. Giuliani, "Dante spiegato con Dante - L'episodio del Conte Ugolino," Jahrbuch der Deutschen Dante-Gesellschaft, IV (1877), 239-71.

Frédéric Guillaume Bergmann, Dante, sa vie et ses oeuvres, 2nd ed. Strassburg: C.F. Schmidt, 1881, p. 284.

Commedia di Dante Allighieri ... esposta e commentata da Antonio Lubin. Padua: L. Penada, 1881.

The Commedia and Canzoniere of Dante Alighieri; a New Translation with Notes, Essays and a Biographical Introduction by E.H. Plumptre, D.D., Dean of Wells. London: Wm. Isbister, 1886-87.

La Divina Commedia di Dante Alighieri col comento di Giovanni Maria Cornoldi. Rome: A. Befani, 1888 [ =1887].

The Divina Commedia of Dante Alighieri, ... with notes by Frederick K.H. Hazelfoot. London: Kegan Paul, Trench, 1887.

La Divina Commedia . . . per cura di Giuseppe Campi. Turin: UTET, 1888-93.

Agostino Bartolini, Studi danteschi, vol. I. Siena, Tip. arciv. S. Bernardino, 1889, pp. 437-39.

La Divina Commedia commentata da Tommaso Casini. $4^{\mathrm{a}}$ ediz., riveduta e corretta. Florence: G.C. Sansoni, 1896. [See also Barbi (1921) and Mazzoni (1972).]

Lezioni espositive popolari sulla Divina Commedia dedicate ai maestri elementari italiani dal Prof. Longoni Baldassare, R. Ispettore Scolastico. Padua: Salmin, 1889.

L'inferno di Dante dichiarato ai giovani da Angelo de Gubernatis. Florence: L. Niccolai, 1891.

La Divina Commedia di Dante con commenti secondo la scolastica del P. Gioachino Berthier. Fribourg: Libreria dell'Università, 1892[-97].

The Hell of Dante Alighieri, edited with Translation and Notes by A.J. Butler. London \& New York: Macmillan, 1892.

Salvatore Betti, Postille alla "Divina Commedia," ed. G. Cugnoni. Città di Castello: Lapi, 1893, p. 151. Nuovo commento alla Divina Commedia di Dante Alighieri per Giacomo Belli. Rome: Tipografia Editrice Romana, 1894. 
F. Martini (1894)

Poletto (1894)

Vernon (1894)

De Leonardis (1895) G. De Leonardis, "Il Conte Ugolino," Giornale

dantesco, III (1895), 392-411.

Passerini (1897)

Acquaticci (1898)

Murari (1898)

Palmieri (1898)

Pascoli (1898)

Oelsner (1900)

F. Romani (1901)

Tozer (1901)

Carroll (1904)

Fornaciari (1904)

Vincent (1904)

Torraca (1905)

La Divina Commedia di Dante Alighieri, nuoza edizione annotata per uso delle scuole da Felice Martini. Turin: G.B. Paravia, [1894].

La Divina Commedia di Dante Allighieri con commento del Prof. Giacomo Poletto. Rome \& Tournay: Desclée, Lefebvre, 1894.

Readings on the Inferno of Dante Based upon the Commentary of Benvenuto da Imola and Other Authorities with Text and Literal Translation by the Hon ${ }^{\text {ble }}$ William Warren Vernon, 2nd ed. London: Methuen, 1906.

La Divina Conmedia di Dante Alighieri novamente annotata da G.L. Passerini. Florence: G.C. Sansoni, 1897-1901. [And see the "nuova edizione interamente rifatta" in 1909 as published by L.S. Olschki, 1911.]

La Commedia di Dante Alighieri riveduta nel testo e commentata da Giulio Acquaticci. Foligno: F. Campitelli, 1898.

Rocco Murari, "Per la tecnofagía del conte Ugolino ma non pel verso 75 del canto XXXIII dell'Inferno," Giornale dantesco, VI (1898), 491-97.

Commento alla Divina Commedia di Dante Alighieri di Domenico Palmieri, S.I. Prato: Giachetti, 1898-99.

Giovanni Pascoli, "Il Conte Ugolino," in his Minerva oscura. Leghorn: Giusti, 1898, pp. 159-76.

The Temple Classics Translation of Dante. London: J.M. Dent, 1899-1901. [Notes to Inf. by H. Oelsner.]

Il Canto XXXIII dell'Inferno letto da Fedele Romani nella sala di Dante in Orsanmichele. Florence: Sansoni, 1901, p. 34.

An English Commentary on Dante's Divina Commedia [by the Rev. H.F. Tozer]. Oxford: Clarendon Press, 1901.

Exiles of Eternity [expositions by John S. Carroll]. London: Hodder and Stoughton, 1904.

La Divina Commedia con postille e cenni introduttivi del Prof. Raffaello Fornaciari. Milan: Hoepli, 1904.

The Divina Commedia of Dante: The Inferno [notes by Marvin R. Vincent, D.D.]. New York: Charles Scribner's Sons, 1904.

La Divina Commedia di Dante Alighieri nuovamente commentata da Francesco Torraca, $4^{\mathrm{a}}$ ediz. riveduta e 
Boselli (1907)

D'Ovidio (1907)

Lisio (1907)

Grandgent (1909)

Langdon (1918)

Olschki (1918)

Casini/Barbi (1921)

Federzoni (1921)

Mestica (1921)

Ricci (1921)

Ricci $\left(1921^{2}\right)$

Steiner (1921)

Rossi (1923) corretta. Milan-Rome-Naples: Albrighi, Segati, 1920.

Olinto Boselli, "La tecnofagia del conte Ugolino," Giornale dantesco, XV (1907), 93-96.

Francesdo D'Ovidio, Nuovi studi danteschi: Ugolino, Pier della Vigna, $i$ Simoniaci, e discussioni varie. Milan: U. Hoepli, 1907, pp. 63-116.

La Divina Commedia commentata ed illustrata ad uso del popolo dal Prof. Giuseppe Lisio. Milan: P. Carrara, 1907.

La Divina Commedia di Dante Alighieri, edited and annotated by C.H. Grandgent. Boston: D.C. Heath, 1909-13. [See also the revised ed. of 1933 (Boston, Heath).]

Espinasse-Mongenet (1913) La Divine Comédie, traduction nouvelle et notes de L. Espinasse-Mongenet. Paris: Les Libraires Associés, 1965 [Inf. 1913].

La Divine Comédie: L'enfer . . . avec une introduction et des notes, par E. de Laminne. Paris: Perrin, 1913.

The Divine Comedy of Dante Alighieri ... with a Commentary by Courtney Langdon. Cambridge: Mass., Harvard University Press, 1918.

La Divina Commedia . . . herausgegeben von $D^{r}$. Leonardo Olschki. Heidelburg: J. Groos, 1918.

La Divina Commedia di Dante Alighieri con il commento di Tommaso Casini, $6^{a}$ ediz. rinnovata e accresciuta per cura di S.A. Barbi. Florence: G.C. Sansoni, 1944. [And see Casini (1889) as well as Mazzoni (1972).]

La Divina Commedia di Dante Alighieri commentata per le scuole e per gli studiosi da Giozanni Federzoni. Bologna: L. Cappelli, 1921-23.

La Commedia di Dante Alighieri . . . esposta e commentata da Enrico Mestica. Florence: R. Bemporad, 1921-22.

Corrado Ricci, "La morte e l'invettiva del conte Ugolino," Giornale dantesco, XXIV (1921), 40-47.

Corrado Ricci, "Ugolino," in his Ore ed ombre dantesche. Firenze: F. Le Monnier, 1921, pp. 201-48. [For extensive bibliography on Ugolino see pp. 235-48.]

La Divina Commedia commentata da Carlo Steiner. Turin: G.B. Paravia, 1921.

La Divina Commedia commentata da Vittorio Rossi e Salvatore Frascino. Milan-Rome: Società Editrice Dante Alighieri, 1941-48. [Rossi's comm. to Inf. Naples, F. Perella, 1923.] 
G. Mazzoni (1924) La Comedia di Dante Alighieri annotata nelle sue bellezze e compendiata nel racconto dell'intero poema da Guido Mazzoni. Florence: F. Le Monnier, 1924.

Scarano (1924)

G.A. Venturi (1924)

La Divina Commedia di Dante Alighieri commentata da Nicola Scarano. [Palermo]: R. Sandron, 1924-28.

Flamini/Pompeati (1925) La Divina Commedia, con commenti, note e La Divina Commedia commentata da Giovanni Antonio Venturi. Milan: C. Signorelli, 1924-26.

saggio proemiale dei proff. F. Flamini ed A. Pompeati [Flamini: Inf. I-XXV; Pompeati: Inf. XXVI-Par. XXXIII]. Milan: F. Vallardi, 1925-30.

Del Lungo (1926) La Divina Commedia commentata da Isidoro del Lungo. Florence: F. Le Monnier, 1926.

Tamburini (1926)

Johnston (1928)

Folingo (1929)

Scartazzini/Vandelli (1929) La Divina Commedia col commento scartazziniano rifatto da Giuseppe Vandelli, $9^{\mathrm{a}}$ ediz. Milan: U. Hoepli, 1929. [Vandelli's first revision of Scartazzini dates from 1903; thus, while one may prefer to use the "definitive" 9th or 10th (1937) edition, one should be aware of the early provenance of many of the glosses.]

Howell (1931)

Wilbur Samuel Howell, "The Method of Dialogue in Dante's Inferno." PhD thesis, Cornell University 1931, p. 286.

Grabher (1934)

Trucchi (1936)

Provenzal (1938)

Vitali (1943)

La Divina Commedia, col commento di Carlo Grabher. Bari: Laterza, 1964-65.

Esposizione della Divina Commedia [da Ernesto Trucchi]. Milan: L. Toffaloni, 1936.

La Divina Commedia, commentata da Dino Provenzal. Milan-Verona: A. Mondadori, 1938.

La Divina Commedia con note e commento di Guido Vitali. Milan: Garzanti, 1943.

Pietrobono (1946 [1924]) La Divina Commedia di Dante Alighieri, commentata da Luigi Pietrobono, $3^{\mathrm{a}}$ ediz. Turin: S.E.I., 1946.

Porena (1946)

La Divina Commedia di Dante Alighieri commentata da Manfredi Porena. Bologna: N. Zanichelli, 194648. 
Rivalta (1946)

Spoerri (1946)

Villaroel (1947)

Lepore (1950)

Falchitto (1952)

Gmelin (1954)

Malagoli (1955)

Raya (1955)

Soprano (1955)

Sapegno (1955)

Montanari (1956)

Mattalia (1960)

Ammendola (1962)

Bianchi/Manetti (1962)

Chimenz (1962)

Marcazzan (1962)

Morvidi (1962)

Sbriccoli (1963)
La Divina Commedia . . . col commento di Ercole Rivalta. Florence: Vallechi, 1946.

T. Spoerri, Einführung in die Göttliche Komödie. Zurich: Speer-verlag, 1946, p. 139.

La Divina Commedia . . . introduzione e commenti di Giuseppe Villaroel. Rome: A. Curcio, 1964.

La Divina Commedia ..., note a cura di M. Lepore. Milan: Viola, [1950-53].

Scoperta del mondo dantesco; esposizione e commento della Divina Commedia [di Sinibaldo Falchitto]. Rome: E. Merlo, 1952.

Die Göttliche Komödie, ubersetzt von Hermann Gmelin. Kommentar. Stuttgart: Klett, 1954-57.

La Divina Commedia, note e commento di Luigi Malagoli. Milan: "La Prora," 1955-56.

Gino Raya, "Il canto di Ugolino," in Studi in onore di Salvatore Santangelo. Catania: Università di Catania, 1955, pp. 188-96.

La Divina Commedia nell'interpretazione e nel commento di Edoardo Soprano. Florence: E. Vallechi, 1955.

La Divina Commedia a cura di Natalino Sapegno. Milan-Naples: R. Ricciardi, 1955.

La Divina Commedia [commentary by Fausto Montanari]. Brescia: "La Scuola" Editrice, 1956.

La Divina Commedia a cura di Daniele Mattalia. Milan: A. Rizzoli, 1960.

A. Ammendola, "Il sogno del conte Ugolino e la sua tecnofagía," in his Appunti danteschi. Naples: "Aurora," 1962, pp. 73-79.

La Divina Commedia commentata da Enrico Bianchi \& Aldo Manetti. Florence: Salani, 1972.

La Divina Commedia di Dante Alighieri a cura di Siro A. Chimenz. Turin: UTET, 1962.

Mario Marcazzan, "Il canto XXXIII dell'Inferno," in Lectura Dantis Scaligera. Florence: Le Monnier, 1967.

Leto Morvidi, "Difesa del conte Ugolino," in his Figure dantesche. Viterbo: Agnesotti, 1962, pp. 129-50.

La Divina Commedia . . coi commenti estetici di Francesco de Sanctis. Note di Lucio Sbriccoli. A cura 
Contini (1965)

Fallani (1965)

Pézard (1965)

Ramat (1965)

Petrocchi (1966)

Russo (1966)

di Franco A. Rigano. Rome: Editrice Italiana di Cultura, 1963.

Gianfranco Contini, "Philology and Dante Exegesis," Dante Studies, LXXXVII (1969), 14-16 [first in Rendiconti dell' Accademia dei Lincei, 1965; now in Varianti e altra linguistica, Turin: Einaudi, 1970, pp. 418-21].

La Divina Commedia a cura di Giovanni Fallani. Messina-Florence: G. D'Anna, 1965.

Oeuvres complètes de Dante Alighieri, traduction et commentaires par André Pézard. Paris: Gallimard, 1965.

Raffaello Ramat, "Il conte Ugolino," in Dante nella critica d'oggi, a cura di Umberto Bosco. Florence: Le Monnier, 1965, pp. 518-27.

La Commedia secondo l'antica vulgata a cura di Giorgio Petrocchi. Milan: A. Mondadori, 1966-67.

Vittorio Russo, "Il 'dolore' del conte Ugolino," in his Sussidi di esegesi dantesca. Naples: Liguori, 1966, pp. 147-81.

Sortino (1967)

Bargellini (1968)

Giacalone (1968)

Petrocchi/Ciotti (1968) La Divina Commedia a cura di Giorgio Petrocchi $\mathcal{E}$

Andrea Ciotti. Padua: R.A.D.A.R., 1968.

Caligaris (1969)

Gallardo (1969)

La Divina Commedia a cura di Matteo Sortino. Catania: Parva, 1967.

La Divina Commedia esposta e conmentata da Piero Bargellini. Florence: E. Vallechi, 1968.

La Divina Commedia a cura di Giuseppe Giacalone. Rome: A. Signorelli, 1968.

Sansone (1969)

Singleton (1970)

La Divina Commedia di Dante Alighieri a cura di Pietro Caligaris. Rome: De Luca, 1969.

La Divina Commedia, Commento di Piero Gallardo. Turin: G.B. Petrini, 1969.

Mario Sansone, "Il canto XXXIII dell'Inferno," in Nuove letture dantesche. Florence: Le Monnier, 1969.

The Divine Comedy, Translated, with a Commentary, by Charles S. Singleton. Princeton: Princeton University Press, 1970-75.

Bàrberi Squarotti (1971) Giorgio Bàrberi Squarotti, "L'orazione del conte Ugolino," Letture classensi, IV (1973), 177-78 [first in Lettere Italiane, XXIII (1971)].

Musa (1971)

Dante's Inferno, Translated with Notes and Commentary by Mark Musa. Bloomington \& London: Indiana University Press, 1971.

Mazzoni (1972) La Divina Commedia [Inf. \& Purg.], con i commenti di T. Casini/S.A. Barbi e di A. Momigliano. Introduzione 
e aggiornamento bibliografico-critico di Francesco Mazzoni. Florence: G.C. Sansoni, 1972-73.

Shapiro (1974)

Marianne Shapiro, "An Old French Source for Ugolino?" Dante Studies, XCII (1974), 129-47.

Bosco (1976)

Umberto Bosco, "Il conte Ugolino nella 'Commedia,'" in ED, V (1976), 799.

Cioffari (1977)

Vincenzo Cioffari, "Il Canto XXXIII dell'Inferno," in Inferno: Letture degli anni 1973-76, Casa di Dante in Roma. Rome: Bonacci, 1977, p. 794.

Freccero (1977) John Freccero, "Bestial Sign and Bread of Angels (Inferno 32-33)," Yale Italian Studies, I (1977), 53-66.

Lonergan (1977) C.S. Lonergan, "The Context of Inferno XXXIII: Bocca, Ugolino, Fra Alberigo," in Dante Commentaries: Eight Studies of the "Divine Comedy," ed. D. Nolan. Dublin: Irish Academic Press; Totowa, NJ, Rowman and Littlefield, 1977, pp. 79-80.

Bosco/Reggio (1979) La Divina Commedia a cura di Umberto Bosco e Giovanni Reggio. Florence: Le Monnier, 1979.

Cook/Herzman (1979) William R. Cook and Ronald B. Herzman, "Inferno XXXIII: The Past and the Present in Dante's Imagery of Betrayal," Italica, LVI (1979), 377-83.

Herzman (1980) Ronald B. Herzman, "Cannibalism and Communion in Inferno XXXIII," Dante Studies, XCVIII (1980), 53-78.

Pasquini (1980) Emilio Pasquini, "Il canto XXXIII dell' 'Inferno,'" Letture Classensi, IX-X (1982), 207-09 [read 8 March 1980].

Boitani (1981) Piero Boitani, "Inferno XXXIII," in Cambridge Readings in Dante's "Comedy," ed. Kenelm Foster \& Patrick Boyde. Cambridge: Cambridge University Press, 1981, pp. 83-84.

Pasquini/Quaglio (1982) Commedia di Dante Alighieri, a cura di Emilio Pasquini e Antonio Quaglio. Milan: Garzanti, 1982. 